\title{
How does tourist perception lead to tourist hesitation? Empirical evidence from Bangladesh
}

\author{
Mohammad Rashed Hasan Polas ${ }^{1}$ (D) $\cdot$ Ratul Kumar Saha ${ }^{2} \cdot$ Mosab I. Tabash $^{3}$ (D)
}

Received: 28 September 2020 / Accepted: 9 June 2021 / Published online: 22 June 2021

(c) The Author(s), under exclusive licence to Springer Nature B.V. 2021

\begin{abstract}
The paper aims to identify the factors that cause prospective tourists' hesitation to travel. The study also examines whether this relationship is mediated by the tourist perception in Bangladesh. The study is of quantitative design, and the relationships between tourist knowledge, tourist health risk, and destination personality with tourist hesitation were explored using a sample of 322 Bangladeshi prospective tourists. The three relationships were also examined through tourist perception. By using cross-sectional data, the researchers hypothesized that tourist knowledge, tourist health risk, and destination personality have a positive and significant effect on tourist hesitation. Besides, the researchers also hypothesized that tourist perception mediates the relationships between tourist knowledge, tourist health risk, and destination personality with tourist hesitation. In this respect, the Smart PLS 3.0 was employed to analyze the data. The results of the study confirm findings of previous related studies by not only highlighting the importance of tourist perception in shaping tourist hesitation but also indicating the way each dimension of tourism either enhances or inhibits the tourist hesitation. The results of the study also reveal a positive and significant relationship between tourist knowledge and tourist health risk with tourist hesitation. The analysis of data showed no conventional relationship between destination personality and tourist hesitation. Accordingly, this study identified the extent to which tourist perception mediates the relationship between tourist knowledge and destination personality with tourist hesitation. Meanwhile, the results of the study indicate the absence of any mediation role of tourist perception between tourist health risk and tourist hesitation. The study outcomes would encourage the government, policymakers, and tourism managements in creating a tailor-made responsiveness program by building a scenario that could offer more prominent sustainable tourism establishments. Besides, the results may assist stakeholders of tourist destinations in understanding tourist perception and the causes of tourist's hesitation.
\end{abstract}

Keywords Tourist knowledge $\cdot$ Tourist health risk $\cdot$ Destination personality $\cdot$ Tourist perception · Tourist hesitation · Bangladesh

Mohammad Rashed Hasan Polas

rashedhasanpalash@gmail.com

Extended author information available on the last page of the article 


\section{Introduction}

Tourism industry has witnessed noticeable growth worldwide due to the economic growth and subsequent improvement of the quality of people's life (Cui et al., 2016; Dwyer et al., 2020). Several studies have identified tourism as a driver of the economic growth of any country (Badulescu et al., 2020; Mishra et al., 2011; Swangjang \& Kornpiphat, 2021; Tang $\&$ Tan, 2015). Innumerable travelers visit different parts of the world to enjoy their leisure time or conduct business activities (Barbhuiya \& Chatterjee, 2020; Bonham et al., 2006; Korstanje, 2011; Lepp \& Gibson, 2003; Pforr, 2009). Despite the growth of the tourism industry worldwide, destination managers are increasingly getting concerned about the factors that create tourist hesitation toward traveling (Drimili et al., 2020; Pal et al., 2021; Pulido-Fernández et al., 2019; Wong \& Yeh, 2009).

In South Asia, for instance, Bangladesh is one of the few countries that is not considered as a favorable destination, despite possessing natural landscapes and friendly people. Bangladesh has its beauty which is peculiar and delicate (Amin, 2017). It has many popular tourist attractions including ancient mosques, sites and temples, archeological sites, the longest sea beach in the world, the hills and woods of Sunderban and the wilderness of Chittagong hills, clans, thousands of rolling tea gardens of globally renowned brands, and islands. It offers a lot of tourist attractions and motivations to convince travelers to pay frequent visits to it. In the Chittagong Division of Bangladesh, Asia, the town of Cox's Bazar in Cox's Bazar is home to the largest unbroken, natural sandy beach in the world, including dumb homes; it is $150 \mathrm{~km}$ long (Majumder \& Iqbal, 2018). Cox's Bazar is probably the leading and most visited tourist destination (Amin, 2017), and it is labeled as the tourist city of choice in Bangladesh. Tourism is the primary source of the economy of Cox's Bazar contributing greatly to the national GDP (Hossain, 2020; Sadar \& Rekha, 2016).

As far as the importance of the travel and tourism industry in the global economy is concerned, the COVID-19 pandemic has done much damage to the vitality of this sector. While COVID-19 is a major contributor to the decline of international tourism sector, few research studies were conducted on the effect of the COVID-19 pandemic on tourism and travel industry in Bangladesh (Hafsa, 2020; Hossain, 2020). With alarming COVID19 related health risks, countries all over the world imposed lockdowns, restrictions on domestic and international flights to prevent the spread of this pandemic. Given such unprecedented circumstances, tourism is badly affected by the restrictions on movement of people and the ban on travel (Deb \& Nafi, 2020). In the past few years, Bangladesh's tourism sector has gradually expanded with a strong domestic travel sector. Nonetheless, tourism and transport activities have remained closed since mid-March 2020 due to travel restrictions. COVID-19 has contributed to dramatic shifts in Bangladesh's lifestyle and economy (Begum et al., 2020) with all forms of economic enterprise being halted by the Government of Bangladesh.

Amid the pandemic, the Asian travel industry sector has been seriously discouraged. The well-performing traveler destinations in Asia including China, Thailand, Singapore, South Korea, Japan, Malaysia, and Indonesia have witnessed a considerable reduction in their tourist arrivals (Berglund et al., 2019; Nhamo et al., 2020) (Fig. 1).

With restricted travel and cancellation of business flights, the lavish hotel industry has likewise been confronting the domino impact of economic fallout. The occupancy rates of luxury hotels declined substantially. While hotels would have witnessed occupancy rates of $80 \%$ in regular times, the current rates have plunged to 30\% (Deb \& Nafi, 2020; Hafsa, 2020; Jabbari et al., 2019). 


\section{Decrease in tourist arrivals in Asia-Pacific countries (percentage)}

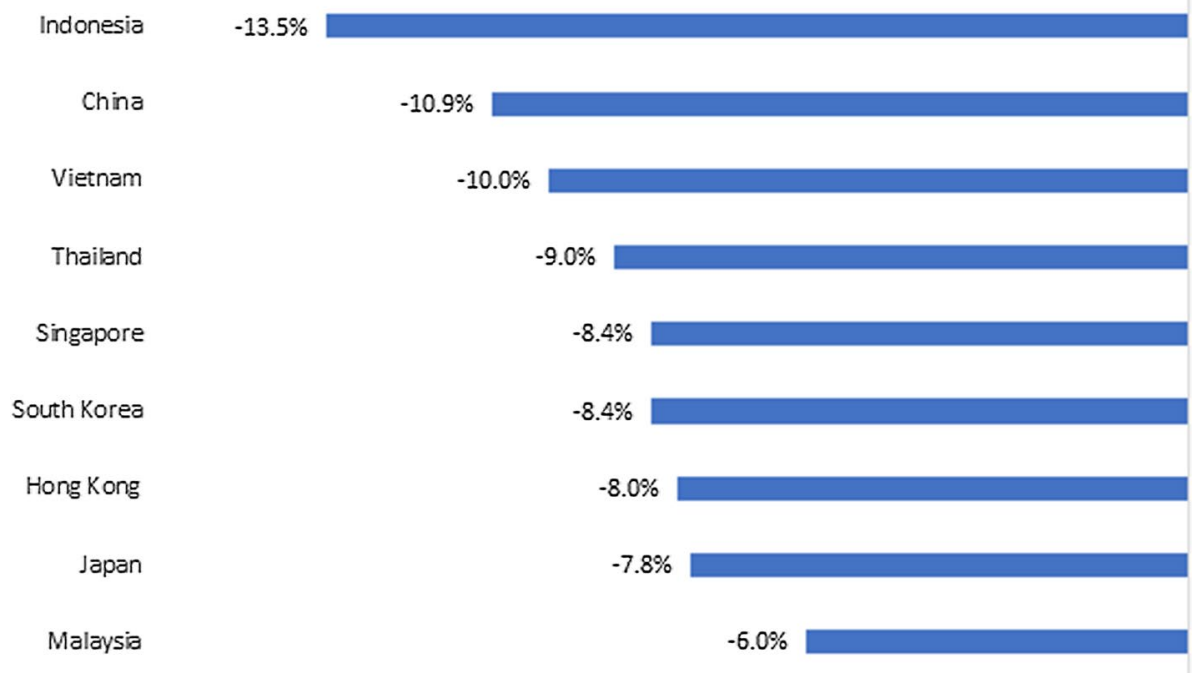

Fig. 1 Decrease in tourist arrivals in Asia-Pacific countries/Source: LightCastle Analytics Wing (2020)

In Cox's Bazar, the main study location, there had been a steady decline in both domestic and foreign tourist visits since it was listed as a red zone by the Government. A striking economic effect of COVID-19 (The Daily Star, 2020), the economy is being weighed. PATA Bangladesh has predicted that by June 2020 the tourism sector in Bangladesh will lose some Tk 9.705 core as a result of the pandemic. Other main tourism centers in the country, like Khulna, Chittagong, Cox Bazar, Rajshahi and others are facing the same scenario due to the COVID-19 pandemic; especially budget hotels. Motels and households which are the ultimate target for low-income people are facing a crisis. Overall, the COVID-19 pandemic affects all tourism sectors in Bangladesh (The Daily Star, 2020) (Fig. 2, Table 1).

WTO has updated 2020 forecasts for worldwide tourist arrival to a negative growth of 1 percent to 3 percent and US \$ 30 to US \$ 50 billion loss in global tourist receipts. The worldwide closure has stopped up the international tourism activities. Hundreds of travel and Tour Companies went bankrupt, and a significant number of small hotels, motels, resorts, restaurants were forced to close down. A huge number of individuals went jobless soon after COVID-19 pandemic. Table 1 shows the determined information of the initial half-year of the tourism industry (Ahmed et al., 2020; Anable \& Gatersleben, 2005; Banik et al., 2020; Hossain et al. 2020).

With the decline of COVID-19 cases in the first wave, tourists started to travel to the tourist places especially to the Cox's Bazar Sea beach in Bangladesh. Around one million tourists rushed to the Cox's Bazar (Tribune, 2021a). All airline and bus tickets were sold out, and around 400 hotels and resorts were scrambling to locate spare rooms for travelers (Tribune, 2021a). Hotel costs have risen dramatically, with the minimum fee for a onenight stay currently ranging from $\$ 35$ to $\$ 85$. This increase in tourist activity came after the decrease in the number of daily Covid-19 cases and fatalities in the country, causing people to be less concerned about the epidemic. After that, all the tourist sites throughout 


\section{Change in occupancy rates of luxury hotels in Bangladesh}

(percentage)

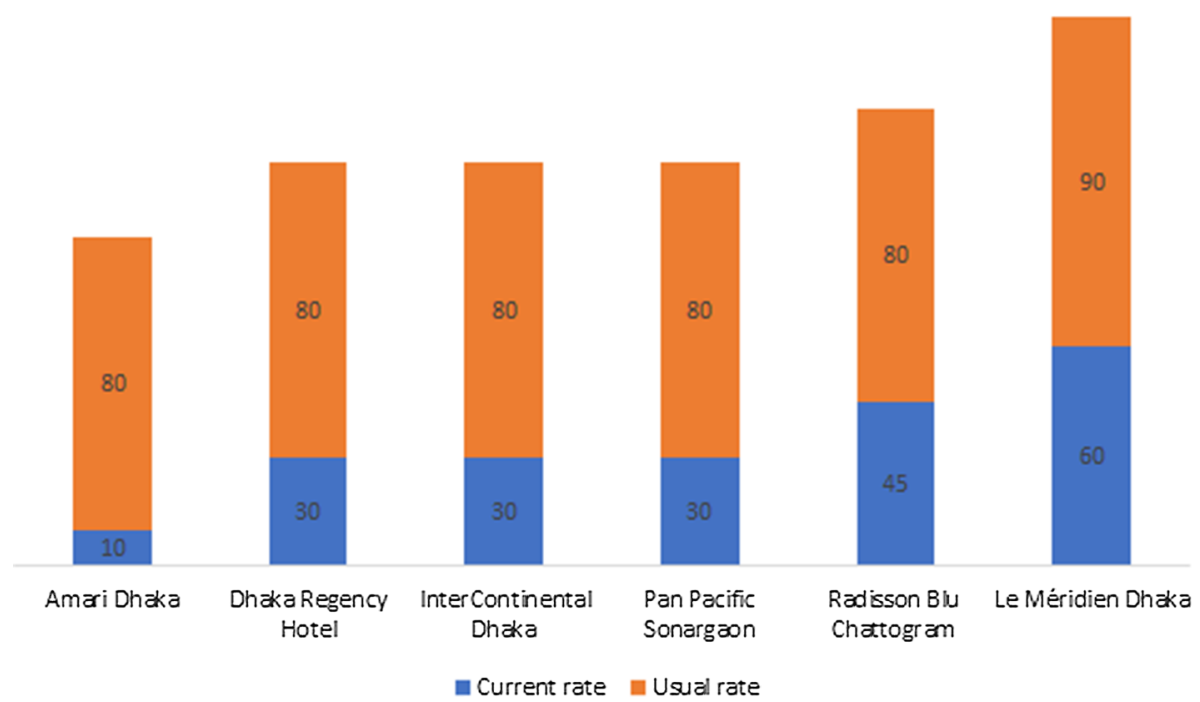

Fig. 2 Change in occupancy rates of luxury hotels in Bangladesh/Source: LightCastle Analytics Wing (2020)

Table 1 Forecasted effect of COVID-19 on the tourism industry

\begin{tabular}{|c|c|c|c|}
\hline No. & Sectors & $\begin{array}{l}\text { Total Taka in crores } \\
\text { (till June 2020) }\end{array}$ & $\begin{array}{l}\text { Total Jobless } \\
\text { (till June } \\
\text { 2020) }\end{array}$ \\
\hline 1 & Aviation: Private airlines & 600 & 2,000 \\
\hline 2 & Hotels/Resorts/Inns $(2 *-5 *)$ & 1500 & $1,00,000$ \\
\hline 3 & Travel A & 3000 & 15,000 \\
\hline \multirow[t]{5}{*}{4} & Tour Operators: & & \\
\hline & Inbound: & 100 & 1,000 \\
\hline & Outbound: ( Land packages only) & 2500 & 15,000 \\
\hline & Domestic: & 1000 & 20,000 \\
\hline & UMRAH (Land packages only) & 450 & 5,000 \\
\hline 5 & Restaurants, coffee shop, first food, BAR and others & 500 & $1,50,000$ \\
\hline \multirow[t]{3}{*}{6} & Transportations directly involve in Tourism: & & \\
\hline & Vehicles using for tourism (Car/Micro/Mini coach) & 40 & 1,000 \\
\hline & Tourist Vessels: & 15 & 500 \\
\hline 7 & $\begin{array}{l}\text { Total turnover in word Tk. Nine Hundred Seventy One } \\
\text { point Five billion }\end{array}$ & Tk. 9,705 crores & $3,09,500$ \\
\hline
\end{tabular}

Source PATA Bangladesh Chapter (2020)

the country along with Cox's Bazar were instructed by the local district government to be prepared for a new (second) wave of Covid-19 (Tribune, 2021b). This caused a disruption to the tourism sector and forced tourist-related activities to halt. 
Results of previous studies have identified certain factors that have considerable impact on tourists' hesitation toward the decision of destination choices (Kogo et al., 2020; Nadeau et al., 2008; Polas et al., 2018; Um \& Crompton, 1990; Uslu \& Akay, 2019). Health, travel expenses, a distance of the destination, and time constraint significantly contributed to the tourists' hesitation toward destination choice (Carvache-Franco et al., 2019; Shaktawat \& Vadhera, 2020; Tepavčević et al., 2019). Fischer et al. (1991) defined travel risk as the probability of a negative outcome from tourists' behaviors during traveling. Boshoff (2002) showed evidence of the influence of travel risk associated with inadequate information available and can on the last moment change tourists' decision (Monsarrat et al., 2019). Liu (2009) observed an increasing trend in which tourists get more aware of risk factors relevant to traveling (Liu et al., 2019; Rezaei \& Maihami, 2019; Zhu et al., 2021).

Empirical research concerning the influence of tourist perceptions on tourist hesitation in the decision-making process is sparse, leaving some crucial questions unanswered in this vital area of study. In the theory of decision-making, it is a style of decision-making that is a more stable feature of the decision-maker, in addition to the usual course (Chen \& Chen, 2019; Lu et al., 2016; Thunholm, 2004). Tourist personality, therefore, tested by model homogeneous behaviors, is not adequate to explain tourist hesitation. In addition, additional concepts, such as tourist motivation and the advantages demanded by models of destination behavior, are not adequate either to explain tourist hesitations, because they cause tourists to visit a destination. Rather, the use of tourists knowledge, health risks and destination personality are fundamental to the proactive hesitation of tourists regarding decisions and policy-making (Xiao \& Smith, 2007), and it is important, to make a marketing decision, to establish efficient contact, campaigns and service delivery, to consider the knowledge of tourists, health risks and the personality of the destination (Gursoy \& McCleary, 2004; Yasin et al., 2017).

Researchers note that the perceptions of risk, while common from consumption experiences are still under investigation. However, the direct influence of tourist perception, the risks to tourist health, and the destination personality are precedents of unwilling tourism (Fermani et al., 2020; Hanefeld et al., 2015; Spector, 2020). Several research studies have explored the relationship between risk perception and hesitation. Some suggest that a high perceived risk increases the hustle and bustle of visitors and impacts hesitation toward tourism decision-making (Beneke et al., 2013; Mason et al., 2016; RussellBennett et al., 2005). Furthermore, the fundamentals of tourist decision-making and travel behavior are thoroughly studied, but there has been a lack of studies incorporating the issue of tourist hesitation due to tourist insufficient perception and knowledge (Jonas \& Mansfeld, 2017; Lalicic \& Önder, 2018; Peng \& Chen, 2019; Polas et al., 2019). Wong and Yeh (2009) investigated the relationship of tourist hesitation with destination decision-making and found evidence of tourists' perceived risk positively influencing the tourist hesitation. There is still great scope for investigating the dynamics of tourist hesitation from different perspectives (Afshar Jahanshahi et al., 2020a, 2020b; Hasan et al., 2017; Islam et al., 2020; Khan et al., 2017a, 2017b; Park et al., 2019). Therefore, it is crucial to find the behavioral issues that demotivate or drive people to hesitate to travel because if tourist hesitation is not properly addressed, it will lead to a lower number of travelers. In this study, we attempted to identify whether health risk perception, tourist knowledge, and destination personality can influence tourists' hesitation to travel to any travel destination. We used tourist perception as a mediating variable for examining these relationships.

The positivist approach, as implemented here, enabled the researchers to seek empirical evidence using the method of hypothetic deductive observation (Polas \& Raju, 2021). In addition, the descriptive research method was introduced as the study contained clear 
problem statements, specific assumptions and a comprehensive body of information (Malhotra, 2004).

\section{Literature review}

\subsection{Hesitation}

The definition of 'Hesitation' has not been explicitly developed in the previous studies, except for the review of Cho et al. (2006), which described it as postponing or postponing sales of products with an additional processing time before the final purchasing of the commodity. It may be invoked both to postpone action and to discourage actions to explain the reasons consumers do not consume it (Ahmed et al., 2020; Badulescu et al., 2020; Dwyer et al., 2020). Although all meanings have to do with reluctance, hesitation cannot be completely explained by the principle of resisting or postponing behavior. Hesitation is a form of choice that relies on different expectations than those defined in early decision-making studies (Beneke et al., 2013; Cahyanto et al., 2016; Fermani et al., 2020). Moreover, the degree of hesitation includes difficulty in executing the planned intervention, and the idea is that people are less likely to establish clear, divisive views of controversial issues, show more ambivalence, and thus are less likely than others to partake in decision-making related behavior (Chen et al., 2019; Cherkani \& Brito, 2018). Thompson and Zanna (1995) prove that the personal anxiety of invalidity is conceptually related to hesitation as it involves the errors and adverse consequences of a judgment embodied in a timid decision (Hafsa, 2020; Wong \& Yeh, 2009). This also suggests that personal fear of invalidity (i.e. risk perception) can be perceived in advance of other factors as a significant personal indicator of hesitation (Cho et al., 2006; Chien et al., 2017; Deb et al., 2020; Gharleghi \& Jahanshahi, 2020).

\subsection{Tourist knowledge}

Tourist knowledge is borrowed from consumer's product knowledge and is a central building block in understanding consumer habits such as information quest (Wijesinghe et al., 2019) and information processing (Kärle et al., 2018; Khan et al., 2017a, 2017b; Kogo et al., 2020; Rezaei \& Maihami, 2019). Delbridge and Bernard, (1998) defined Knowledge as the whole of facts and values gathered by mankind about a specific area. In cognitive psychology, knowledge has been divided into declarative knowledge and procedural knowledge. Declarative knowledge includes accumulated knowledge about facts, theories, and interrelations; those are possible to communicate verbally (Artuğer, 2015; Peng \& Chen, 2019; Zou \& Meng, 2020). On the other hand, procedural knowledge is related to the skills required in the performance of any task (Cohen \& Squire, 1980; Gabrieli, 1998; Lee et al., 2011; Polas et al., 2020). In an attempt to define tourist knowledge, Tsaur et al. (2010) showed that travel-related information and skills represent tourists' perception of associated knowledge about any travel. In this case, declarative knowledge refers to tourist's perception of the specific travel destination and procedural knowledge denotes the practical use the knowledge by tourists in the traveling period starting from planning to the end of the trip (Banik et al., 2020; Begum et al., 2020; Hanefeld et al., 2015; Hasan et al., 2017). 


\subsection{Tourist health risk}

Peattie et al. (2005), defined tourist health risk as the probability of suffering from diseases or other health complexities due to the exposure to any traveling experiences. The existing literature on tourism posited travel as a complex process innately containing a significant level of uncertainties and risks that make the tourism sector highly vulnerable (Bhattacharjee et al., 2018; Fuchs et al., 2013; Polas et al., 2019; Williams \& Baláž, 2015). Jonas et al. (2011) identified tourist health risk as an inseparable part of traveling which has endangering impact on the safety and security of the tourists that enhances their hesitation to travel. On the top, risk perception regarding health has become an important consideration for tourists due to the growing trend of developing a sense of safety among tourists facilitated by the increased availability of information, and these risk perceptions would have an impact on travel hesitation toward decisions of tourists (Cahyanto et al., 2016; Jonas et al., 2011; Khan et al., 2017a, 2017b; Page, 2009).

\subsection{Destination personality}

The concept of destination personality is quite contemporary in the existing literature on tourism (Hosany et al., 2006; Polas et al., 2017; Majumder et al., 2018; Lin et al., 2019; Li et al., 2020). Positioning travel destinations based on their basic characteristics are prone to the risk of being less unique and easily replicable. To create a unique position of travel destination and attract more tourists, additional attributes like destination personality may be proven fruitful (Baloglu et al., 2014; Ekinci \& Hosany, 2006; Tjiptono \& Yang, 2018; Usakli \& Baloglu, 2011). Chen and Phou (2013) showed that the idea of destination personality is applied by destination marketers to brand their places in modern-day severely competitive tourism industry. Additionally, they suggested destination personality as an important metaphor for travel destination branding. The idea of destination personality comes from Aaker's brand personality model. According to Aaker (1997), the brand personality is defined as "the set of human characteristics associated with a brand". "A well-established brand personality aids in the development of favorable brand evaluations, which leads to brand preference and loyalty" (Bhattacharjee et al., 2018; Biel, 1993; Sung \& Kim, 2010). Based on Aaker's framework, Ekinci and Hosany (2006) described destination personality as "the set of human characteristics associated with a destination as perceived from a tourist viewpoint."

\subsection{Tourist risk perception}

The perception of tourists as an option of travel is important for the destination. In the past, scholars have defined perception as a "subjective sense of certainty of the person that the consequences will be unfavorable" and "the amount lost if the effects of an act were not beneficial" (Carballo et al., 2017; Cui et al., 2016; Mishra et al., 2011; Mohamad et al., 2012). It is not possible for prospective travelers to criticize tourist attractions that do not meet travellers' expectations and the desired goals. It is wise to be mindful that the risk of terrorism is seen as expensive rather than secure at a given destination (Carballo et al., 2017; Monsarrat et al., 2019; Ngo et al., 2019). Tourism is often perceived to be a consumer practice (Pan \& Ryan, 2007; Yang et al., 2015). There is also a possibility that the goods or facilities will not meet the expectations of 
tourists or that they will accumulate variables beyond the scope of tourist use (Yang et al., 2015). The evolution of the 'risk' concept (Cui et al., 2016; Peng \& Chen, 2019) in tourism as a two-dimensional synthesis means that there is a possibility for tourists on a trip or a tourist destination to be variously unfortunate (Garg, 2015) and the implications and detrimental consequences for tourists after making travel decisions (Carballo et al., 2017; Cui et al., 2016; Pulido-Fernández et al., 2019).

According to Dhebar (1996), any consumer's perception of risk may make him/her regret an earlier purchase or hesitate to buy a new product (He et al., 2018; Suhartanto et al., 2020). Cho et al. (2006) argued that customer hesitation can be viewed as a tendency to delay or quit the purchase, and consumer perception influences this hesitation. Two theories support the role of tourist risk perception toward tourist hesitation in this study which are Anderson's (1981) information integration theory (IIT) and Roger's (1975) protection motivation theory (PMT) (Sönmez \& Graefe, 1998; Pulido-Fernández et al., 2019). Together, IIT and PMT suggest that future travel behavior would be influenced by images of security and risk that individuals have of regions (Hew et al., 2018; Sönmez \& Graefe, 1998; Su \& Swanson, 2019).

\subsection{Hypotheses development}

\subsubsection{Tourist knowledge and tourist hesitation}

In our first hypothesis, we assumed that the level of individual tourist's knowledge will have a positive impact on hesitation toward the traveling decision. While deciding on a travel destination, tourist gathers all the relevant information including risk factors about visiting the place (Hasan et al., 2017; Li et al., 2020; Peng \& Chen, 2019; Tang \& Tan, 2015; Zou \& Meng, 2020). According to Dolnicar (2007), the tourist's knowledge of the risks and precise perceptions regarding safety has a strong impact on travel decisions. If alternatives available involve risk, the decision-makers tend to delay or quit taking decisions concerned (Dhar, 1997; Tjiptono \& Yang, 2018; Uslu \& Akay, 2019). In a research paper conducted on online consumer behavior, Cho et al. (2006) defined such a behavior involving delay in decision-making as hesitation by itself. Tourists have started to perceive traveling worldwide as unsafe due to the recent emergence of deadly contagious viruses like COVID-19 (Zhu et al., 2021; Zou \& Meng, 2020). We have assumed that this perception will be likely to last even the pandemic is over. Additionally, Glaesser (2003) showed that perceived risk has more influence than actual risk that enhances hesitations and tourists make their travel decisions (Jiang \& Ritchie, 2017; Ngo et al., 2019; Sadar et al., 2016; Shaktawat \& Vadhera, 2020; Spector, 2020). Thus, we hypothesize the following,

H1 There is a positive and significant relationship between tourist knowledge regarding different risks and tourist hesitation.

\subsubsection{Tourist Health Risk and Tourist Hesitation}

In our second hypothesis, we predicted that a positive and significant relationship exists between tourist health risk and tourist hesitation in this new pandemic situation. Fuchs and Reichel (2006) showed travel destination-specific attributes, such as rough weather, natural calamities, and diseases, make a contribution to the tourists' risk perception (Garg, 2015; Hew et al., 2018; Zou \& Meng, 2020). According to Page (2009), health risks, generally 
exposed by tourists, are not life-threatening. Health risk perception toward any travel destination is associated with individual health and safety (Hossain, 2020; Jonas et al., 2011; Li et al., 2020; Peng \& Chen, 2019). Chien et al. (2017) posited that the way tourists perceive health risk, involving any travel destination, has a significant impact on their decisions to go there and the level of preventive measures they take before traveling. They also recognized the growing importance of studies on health risks associated with tourism. The highly transmittable and life-threatening nature of different diseases has exposed tourists to unprecedented health risk which is likely to have a positive impact on the tourist hesitation regarding travel decision (Hasan et al., 2017; Islam et al., 2020; Kogo et al., 2020; Li et al., 2020; Ngo et al., 2019). Thus, we hypothesize the following,

H2 There is a positive and significant relationship between tourist health risk and tourist hesitation.

\subsubsection{Destination Personality and Tourist Hesitation}

In our third hypothesis, we hypothesized that there is a negative and significant relationship between destination personality and tourist hesitation due to the COVID-19 situation. There is some evidence of successful development of destination personality. For example, London is recognized as liberal, unorthodox, and creative, Spain as welcoming and family-oriented, and Paris as a heaven of lovers (Morgan \& Pritchard, 2002; Majumder et al., 2018; Lin et al., 2019; Mohebali et al., 2019; Li et al., 2020; Nhamo et al., 2020). Ekinci and Hosany (2006) confirmed this perspective by showing that popular tourist attractions are affluent in terms of symbolic values associated with histories, legends, emotions, and events. Several studies investigated the relationship between destination personality and tourists' behavioral intentions (Hosany et al., 2006; Hultman et al., 2015; Park et al., 2019; Peng \& Chen, 2019; Usakli \& Baloglu, 2011; Zeugner-Roth \& Zabkar, 2015). These studies showed that positive destination personality increases the visit intentions of tourists, and poor destination personality demotivates travelers. The occurrence of pandemics, such as Covid-19, has brought remarkable change in today's world. The personality of the travel destination would get new dimensions taking health issues into travelers' account. Poor disease control could make any travel destination personality undesirable (Badulescu et al., 2020; Begum et al., 2020; Cherkani \& Brito, 2018; Thai \& Yuksel, 2017). Thus, we hypothesize the following,

H3 There is a positive and significant relationship between undesirable destination personality and tourist hesitation.

\subsubsection{The mediation role of tourist perception}

In our last three hypotheses, we assumed that tourist perception plays a mediation role in the association between tourist knowledge, tourist health risk, and destination personality with tourist hesitation. While assessing the consumer knowledge, Park et al. (1994) showed that subjective form of knowledge is consumers' perception of their understanding of a product category which helps them to make any purchase decision (He et al., 2018; Huat et al., 2019; Suhartanto et al., 2020). Furthermore, Berger et al. (1994) confirmed that subjective product knowledge has an impact on future purchase behavior. Sonmez \& Graefe (1998) showed that the perception of safety and risk that tourists have about any travel 
destination influences a tourist's future travel intention. Therefore, Floyd and PenningtonGray (2004) also emphasize the importance of the study of the tourist risk perception as there is evidence of association of higher risk with decreased visitation (Deb et al., 2020; Drimili et al., 2020). In the context of the tourism industry, a more comprehensive perspective of understanding tourist perception of risk includes evaluating tourists' health concern both in terms of perception of susceptibility and severity (Banik et al., 2020; Cahyanto et al., 2016). Additionally, Chien et al. (2017) expressed that perception of tourists of health risk is one of the critical inputs in tourist's decision-making method (Chen et al., 2019; Suhartanto et al., 2020).

According to Gartner (1986), the total image of any travel destination is formed from the interaction of tourist perceptions of attributes of the destination including all the attractions and happenings within the area. Murphy et al. (2000) claimed that a positive relationship exists between the tourists' understanding of the atmosphere, infrastructure, value, and willingness to revisit their perceptions and experiences. Gill and Ibrahim (2005) also confirmed the impact of the image of any destination on the tourist perception in terms of environment, safety, and comfort (Islam et al., 2020; Lin et al., 2019; Mohebali et al., 2019). On the top, Mohamad et al. (2012) posited that tourist perception has an influence on tourists' forthcoming behavioral intents based on the study conducted on overseas tourists in Malaysia. According to Walker and Page (2003), tourist's perception of risk varies based on the level of intensity and severity. For instance, risks like the probability of terrorist attack are infrequent, but the magnitudes of such events are high, while travel health hazards normally have high frequency with minor severity. This argument is not that strong in the present scenario since diseases such as COVID-19 expose travelers to life-threatening risks. Therefore, we assumed that tourist knowledge, tourist health risk and destination personality influence tourist hesitation to travel with mediation effect of tourist perception (Chen \& Chou, 2019; Hossain, 2020; Suhartanto et al., 2020) (Fig. 3). We hypothesize the following.

H4 Tourist Perception mediates the relationship between tourist knowledge and tourist hesitation.

H5 Tourist Perception mediates the relationship between tourist health risk and tourist hesitation.

H6 Tourist Perception mediates the relationship between destination personality and tourist hesitation.

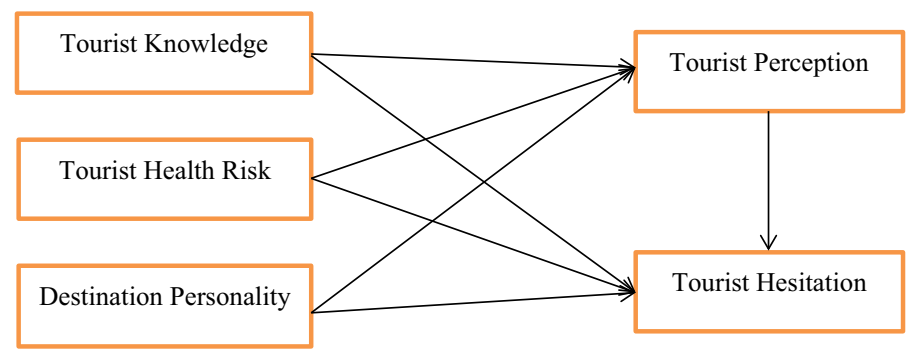

Fig. 3 The framework of the study 


\section{Research methodology}

\subsection{Research design}

In this study, positivism as an approach is employed. This approach allows researchers to discover empirical information using a hypothetical deductive observation process (Polas $\&$ Raju, 2021). The descriptive method of research was also used as the study involved particular problems, specific assumptions and a comprehensive set of knowledge (Malhotra, 2004).

\subsection{Measurement development}

In order to compare the various layouts, validated items have been added and revalidated for the current study. Both focus constructs for this model have been measured by literature-based reflective constructs and are structured to simplify measures using the Likert five-point scale, ranging from (1) 'strongly disagree' to (5) 'strongly agree.' Our 25-item questionnaire satisfies the minimum criteria for a rigorous instrument for Hair et al. (2014). The five variables of the model are as follows: tourist knowledge from Wong \& Yeh (2009); tourist health risk from Wong \& Yeh (2009); destination personality from Lee \& Xie (2011); tourist perception from Lee \& Xie (2011); and tourist hesitation from Lee \& Xie (2011). Each of these variables is composed of four items from the stated sources. Later, a small survey was conducted through online forms to measure intention to revisit destination with reference to the COVID-19 pandemic. It consisted of three items adapted from Artuğer (2015).

\subsection{Sampling and data collection}

To test our hypotheses, a sample of 451 tourists was randomly selected to conduct the survey; all visited the city of Cox's Bazar between December 2019 and January 2020. Following the quantitative analysis, data were collected through a survey method following the cross-sectional design. In addition, our sample data were obtained by non-probability (convenience) sampling, while a team of trained research assistants contributed to the processing of sample data. Moreover, convenience sampling has led to the management of our limited resources. We excluded 129 questionnaires as it was incompletely provided by the tourists. A lack of faith in the survey may be the likely cause. We have also ensured that tourists can take part in face-to-face visits only after visiting the areas as tourists. In general, our results meet the criteria of Comrey and Lee (1992) for a good sample size. The final complete 322 samples were used to get the study outcomes. The response rate was 71.40 percent.

Cox's Bazar (World Longest Sea Beach) is one of the main cities receiving tourists (both national and international) in Bangladesh. Among 322 samples, 29 samples (9\%) were foreign tourists (USA, Canada, Sweden, Japan, China and India) and 293 samples (91\%) were local tourists. Due to first identification of COVID-19 on December 2019 in Wuhan, China, the situation was affected by the cancelation of domestic and international flights. Visas are consequently still being denied to tourists from all countries. Normality tests were conducted using Kolmogorov-Smirnov and Shapiro-Wilk tests (SPSS V.25 analysis), both revealed that the appropriate value ( $p$ value) is greater than 0.05 . It can be concluded that the data seem to be normally distributed. In addition, we assume that our findings are 
roughly marginally skewed in terms of skewness (0.74) and curtosis (1.02), with all $z$ values below \pm 1.96 (SPSS V.25 analysis) but without any concern. Later, a small survey was conducted to measure the intention to revisit destinations in light of the COVID-19 pandemic through online forms and various traveling groups on social media which consists of three items (see Appendix). We received 90 complete and usable responses in this regard.

In order to extend the potential for further credible responses, we have made our survey brief and conceivable. Operating brief surveys broaden our potential for more legitimate responses. Each survey was still close to five minutes away. To boost accuracy, the initial survey was translated into a local language (Bengali) using the dual-back-translation process. To consider the respondents' interpretation of the survey items and to enhance the reliability of the questionnaire, the survey was pre-tested on 28 respondents. These respondents were excluded from the final samples. To lessen social desirability bias, we guaranteed all respondents anonymity and confidentiality in the introductory letter of the study. We used a time-trend extrapolation test to identify the non-response bias suggested by Armstrong and Overton (1977) and commonly used Business, psychology, and business academics. A comparison between the two early respondents (first 25\%) with late respondents (late 25\%) proved that our results are susceptible to non-response bias.

\subsection{Data analysis}

Structural equation modeling (SEM) is widely used to facilitate mediation and measurement of dynamic relationships (Hair et al., 2014; Zheng \& Lu, 2011). Hypotheses were tested with Smart PLS 3.0 instruments in this study. The sample size is the main determinant for SEM and the minimum sample size proposed by Hair et al. (2014) using the minimum R-square method has been surpassed in our case. Smart PLS 3.0 was used to validate the data interpretation and to test the validity and reliability of the research model.

\subsection{Results from analysis}

For the evaluation of the study model and outcomes, Smart PLS 3.0 (SEM-Structural Equation Modeling) was applied in this study. A sample of 322 Bangladeshi respondents participated in the study (Table 2).

The demographic profile of the respondents is seen in Table 1. As seen in Table 1, $59.63 \%$ of respondents were male, $13.98 \%$ were $18-22$ years of age, $62.42 \%$ were single, $55.59 \%$ of the respondents were undergraduate and $25.78 \%$ of the respondent's monthly income was between USD 250-500.

\subsection{Measurement of model assessment}

Model assessment is an integral part of any research based on some measurements or assumptions. Here, Table 3 below shows the factors loadings of items, AVE values, Composite Reliability (CR), Cronbach's alpha values, $R$ square values and NFI value which claim the recommended values.

Table 3 shows that the AVE value of every variable is above 0.50 and the value of $\mathrm{CR}$ and Cronbach's Alpha is above 0.70 and the value of factor loadings is above 0.60 which are the suggested or accepted range. The NFI value is 0.899 which is close to the accepted range. Therefore, the conceptual model is best fit with the study objectives 
Table 2 Respondent's demographic profile

\begin{tabular}{|c|c|c|}
\hline Characteristics & Frequency & Percentage \\
\hline \multicolumn{3}{|l|}{ Gender } \\
\hline Male & 192 & 59.63 \\
\hline Female & 130 & 40.37 \\
\hline \multicolumn{3}{|l|}{ Age } \\
\hline 18-22 Years & 45 & 13.98 \\
\hline 23-27 Years & 81 & 25.16 \\
\hline 28-32Years & 78 & 24.22 \\
\hline 33-37 Years & 67 & 20.81 \\
\hline 38 Years or above & 51 & 15.84 \\
\hline \multicolumn{3}{|l|}{ Marital status } \\
\hline Single & 201 & 62.42 \\
\hline Married & 114 & 35.4 \\
\hline Divorced & 7 & 2.17 \\
\hline \multicolumn{3}{|l|}{ Separated } \\
\hline \multicolumn{3}{|l|}{ Window } \\
\hline \multicolumn{3}{|l|}{ Education level } \\
\hline SSC & 17 & 5.27 \\
\hline HSC & 29 & 9 \\
\hline Under Graduate & 179 & 55.59 \\
\hline Post Graduate & 97 & 30.12 \\
\hline \multicolumn{3}{|c|}{ Monthly Income (US Dollar) } \\
\hline $250-500$ & 83 & 25.78 \\
\hline $501-750$ & 67 & 20.81 \\
\hline $751-1000$ & 78 & 24.22 \\
\hline $1001-1250$ & 66 & 20.5 \\
\hline $1251-1500$ & 28 & 8.7 \\
\hline Total & 322 & \\
\hline
\end{tabular}

and hypotheses (Hair et al., 2014). From Table 3 above, it is visible that $R^{2}$ indicates the values of the variances of the endogenous variable(s). Usually, by three different effects, the value of $R^{2}$ is denoted which is small $\left(R^{2}=2 \%\right)$, median $\left(R^{2}=13 \%\right)$ and large effect $\left(R^{2}=26 \%\right)$ (Polas \& Raju, 2021). Here, tourist hesitation is demonstrated by a large effect $(0.914$ or $91.40 \%)$ with exogenous variables. Then, tourist perception is also stated by $(0.904$ or $90.40 \%)$ large effect with exogenous variables.

\subsection{Discriminant validity: Fornell-Larcker criterion}

To evaluate the discriminate validity for assessing the model, the Fornell-Larcker criterion (1981) was applied. Table 4 shows the values of correlations between the LV (Latent Variables) and square roots of the AVE values in the main diagonal in the SEM. Moreover, the square root of the AVE (in bold) of all variables describes the highest within a range of $0.839-0.872$. Thus, it is well comprehensible that discriminant validity is sustained between variables and accredited for this estimated model of the study. 
Table 3 Measurement of model assessment

\begin{tabular}{|c|c|c|c|c|c|c|c|}
\hline Constructs & Items & Loading & AVE & CR & Alpha & R-Square & NFI \\
\hline & TK1 & 0.776 & & & & & \\
\hline \multirow[t]{4}{*}{ Tourist knowledge (TK) } & TK2 & 0.905 & 0.704 & 0.858 & 0.904 & & \\
\hline & TK3 & 0.810 & & & & & \\
\hline & TK4 & 0.859 & & & & & \\
\hline & THR5 & 0.844 & & & & & \\
\hline \multirow[t]{4}{*}{ Tourist Health Risk (THR) } & THR6 & 0.847 & 0.720 & 0.870 & 0.911 & & \\
\hline & THR7 & 0.859 & & & & & \\
\hline & THR8 & 0.843 & & & & & \\
\hline & DP9 & 0.885 & & & & & \\
\hline \multirow[t]{4}{*}{ Destination Personality (DP) } & DP10 & 0.846 & 0.744 & 0.885 & 0.921 & & 0.899 \\
\hline & DP11 & 0.886 & & & & & \\
\hline & DP12 & 0.833 & & & & & \\
\hline & TP13 & 0.909 & & & & & \\
\hline \multirow[t]{4}{*}{ Tourist Perception (TP) } & TP14 & 0.785 & 0.760 & 0.893 & 0.926 & 0.904 & \\
\hline & TP15 & 0.875 & & & & & \\
\hline & TP16 & 0.912 & & & & & \\
\hline & TH17 & 0.894 & & & & & \\
\hline \multirow[t]{3}{*}{ Tourist Hesitation (TH) } & TH18 & 0.950 & 0.760 & 0.893 & 0.926 & 0.914 & \\
\hline & TH19 & 0.781 & & & & & \\
\hline & TH20 & 0.852 & & & & & \\
\hline
\end{tabular}

Table 4 Values of correlations between the LV and square roots of the AVE values in the main diagonal in the SEM

\begin{tabular}{lllllll}
\hline & & 1 & 2 & 3 & 4 & 5 \\
\hline 1 & Destination Personality & $\mathbf{0 . 8 6 3}$ & & & & \\
2 & Tourist Health Risk & 0.766 & $\mathbf{0 . 8 4 8}$ & & & \\
3 & Tourist Hesitation & 0.781 & 0.815 & $\mathbf{0 . 8 7 2}$ & & \\
4 & Tourist Knowledge & 0.675 & 0.744 & 0.676 & $\mathbf{0 . 8 3 9}$ & \\
5 & Tourist Perception & 0.684 & 0.759 & 0.743 & 0.777 & $\mathbf{0 . 8 7 2}$ \\
\hline
\end{tabular}

The diagonal is the square root of the AVE (in bold) of the latent variables and indicates the highest in any column or raw

\subsection{Structural model assessment}

Structural model assessment is another crucial part of figuring out its validity. Figure 4 shows the structural model assessment. Using the bootstrapping process with a resample 500 was also implemented to figure out the $t$ values and $R$ square.

\subsection{Hypotheses Testing}

Table 5 shows the results of direct and indirect effect hypotheses by running SEM where the hypothesis was tested. In the first hypothesis, we presumed that a higher level of tourist 


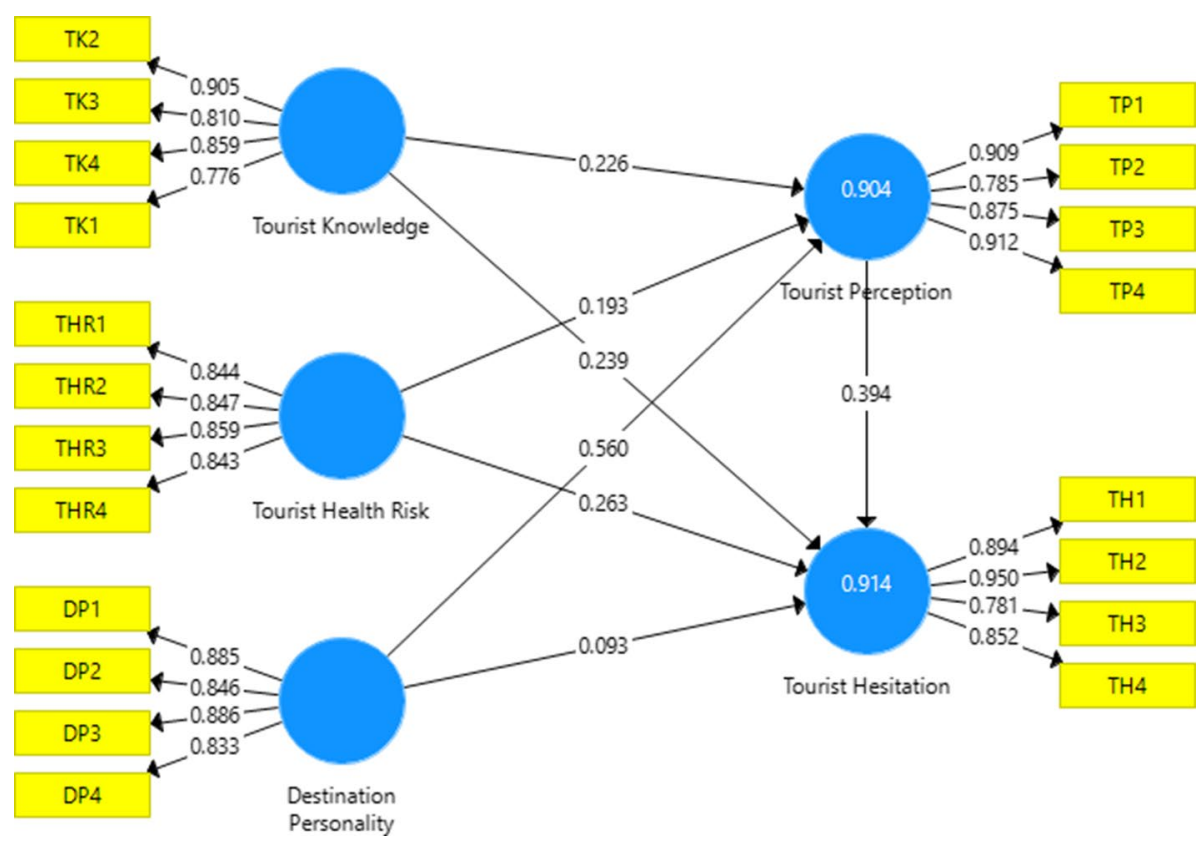

Fig. 4 Standardized results of SEM calculations

knowledge influences tourist hesitation. In Table 5, a positive and significant relationship is found between tourist knowledge and tourist hesitation $(\beta=0.237, t=3.034, p<0.05)$. Hence, hypothesis 1 is sustained. In the second hypothesis, we assumed that tourist health risk has a positive effect on tourist hesitation. In Table 5, a positive and significant relationship is found between tourist health risk and their tourist hesitation $(\beta=0.261, t=3.936$, $p<0.05)$. Thus, hypothesis 2 is supported. In the third hypothesis, we predicted that destination personality has a positive effect on tourist hesitation. In Table 5, a positive but insignificant relationship is found between destination personality and tourist hesitation $(\beta=0.095, t=1.051, p>0.05)$. Thus, hypothesis 3 is not supported.

Furthermore, in the fourth hypothesis, we expected that tourist perception mediates the relationship between tourist knowledge and tourist hesitation. Table 5 shows that tourist perception mediates the connection between tourist knowledge and tourist hesitation perfectly $(\beta=0.088, t=2.647, p<0.05)$. Thus, hypothesis 4 is supported. In the fifth hypothesis, we assumed that tourist perception mediates the relationship between tourist health risk and tourist hesitation. Table 5 shows that tourist perception does not mediate the connection between tourist health risk and tourist hesitation perfectly $(\beta=0.079, t=1.441$, $p>0.05$ ). Thus, hypothesis 5 is rejected. In the sixth hypothesis, we expected that tourist perception mediates the relationship between destination personality and tourist hesitation. In Table 5, we found that tourist perception mediates the connection between destination personality and tourist hesitation perfectly $(\beta=0.221, t=3.610, p<0.05)$. Thus, hypothesis 6 is proved right.

Table 6 shows the tourist's intention to revisit the destination in light of COVID-19. In Table 6, when tourists were asked "If I come to travel again, my first choice will be Cox's Bazar?, $37.8 \%$ of tourists strongly agreed to revisit this tourist destination in light of the COVID-19 pandemic. Further, they were asked the question "I plan to come to 


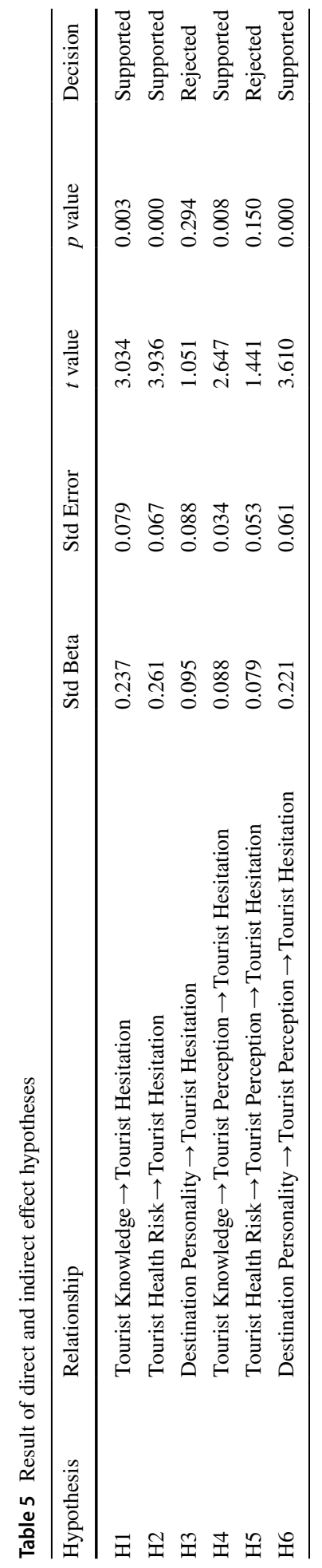


Table 6 Intention to Revisit Tourist Destination (COVID-19 Perspective)

\begin{tabular}{lllllc}
\hline Items & Mean & Std. Dev & Likert Scale & Frequency & Percent \\
\hline \multirow{4}{*}{ Item 1 } & \multirow{2}{*}{3.75} & \multirow{2}{*}{1.202} & Strongly Disagree & 3 & 3.3 \\
& & & Disagree & 13 & 14.4 \\
& & & Not Sure & 21 & 23.3 \\
& & & Agree & 19 & 21.1 \\
& & & Strongly Agree & 34 & 37.8 \\
& & & Strongly Disagree & 2 & 2.2 \\
Item 2 & \multirow{2}{*}{3.70} & \multirow{2}{*}{1.043} & Disagree & 10 & 11.1 \\
& & & Not Sure & 24 & 26.7 \\
& & & Agree & 31 & 34.4 \\
& & & Strongly Agree & 23 & 25.6 \\
& & & Strongly Disagree & 2 & 2.2 \\
Item 3 & \multirow{3}{*}{3.63} & \multirow{2}{*}{1.033} & Disagree & 12 & 13.3 \\
& & & Not Sure & 22 & 24.4 \\
& & & Agree & 35 & 38.9 \\
& & & Strongly Agree & 19 & 21.1 \\
& & & Total- 90 & & \\
\hline
\end{tabular}

Cox's Bazar again in the future," $34.4 \%$ of tourists agreed to revisit the tourist destination. Finally, when tourists were asked the question "The probability that I come to Cox's Bazar again for holidays is high," $38.9 \%$ of tourists agreed to revisit the destination. Overall, it is assumed that tourists have an intention to revisit destinations in light of COVID-19 as they are bored and exhausted due to movement restrictions. In this regard, they are seeking refreshment to boost their mental health.

\section{Discussion}

This research attempted to explain whether tourists are halting or postponing or even changing their destination and path choices with the effects of knowledge, health risk and personality destination or not. Through the development and testing of a structural model using SEM (SmartPLS 3.0), this study examined several concepts in the literature on tourist knowledge, tourist health risk, destination personality, tourist perception and hesitation. Test results explicitly indicated that tourist knowledge and health risk have a positive and significant effect on the hesitation and tourist perception to mediate ties between tourist knowledge and destination personality with hesitation.

Previous studies were also connected with the behavior of tourism decision-making in detail, while tourist hesitation remained underestimated to date. Tourist knowledge and health risk are considered to be the main independent indicators of effect in the current study, focused on the customer's decision-making and behavioral theory. In addition, the above relationship has been relatively overlooked by the current study. Although it is difficult to eliminate tourist health risks, previous researchers proposed that tourist practitioners increase tourists' willingness to travel to tourism destinations by reducing their perception of risk. Most have noted how perceptions of tourist risks have been reduced. Accordingly, this study uses the knowledge of tourists to adjust the impact of interpreting the risk of tourists on hesitation. Empirical results are consistent with Cho et al. (2006) findings that the greater the knowledge and 
risk to the health of consumers when deciding on their purchases, the more likely they are to doubt their decision-making. One potential explanation in the field of tourism is that, during the decision-making process, tourists cannot show the consistency of their offerings using the intangibility of tourism similar information, which makes it difficult for them to recognize and even envisage changing their previous choices.

However, in terms of the theoretical framework with the mediating solution of tourist perception, the present study varies from that of Cho et al. (2006). Based on the previous research, two key perspectives are established; first, subjective product knowledge is closely linked to purchasing confidence. Second, it is subjective product knowledge which decides purchases rather than objective product knowledge. Based on the results, if the tourist thinks that he already knows a certain destination, the effect of the interpretation of the tourist risk on hesitation is minimized, so it is easier for the tourist to make decisions on the spot visit. This discovery not only supports the results of the previous study but also shows the value of contextual product knowledge in both theory and tourism.

Generally speaking, hesitation is inaccurate if no risk is assumed to exist when tourists fail to decide on destinations and routes. Tourist hesitation makes it impossible for tourism practitioners to persuade clients to take an immediate decision on procurement and to improve the willingness of prospective customers to move to other travel agencies and thereby negatively impact sales efficiency. Moreover, when tourists themselves are concerned, hesitation is likely to result in a lack of choice of tours due to the seasonal nature of the tourism services, whereas other travel agencies with different prices and routes could be able to choose the same tours. However, it needs more time and money to look at the evidence and make new choices. Tourists should also work on reducing the volume of tourism hesitation.

Tourism and marketing practices are now focused instead on on-the-spot sales systems, infrastructure, and web interface design. Tourists will learn more about destinations and itineraries from the web interface. However, this approach raises questions as to whether the contents of the websites reflect the real products accurately (Afshar Jahanshahi et al., 2020a, 2020b). If the tourism administrators are unable to discuss the particulars of the trips with the tourists at their initial meeting in a sincere way, tourism will definitely miss the participation of a significant component of the industry. This study suggests that tourism managers should establish subjective, target-relevant object knowledge and provide complete tangible descriptions. In advertising campaigns with a direct effect upon consumers, regular competition for products of tourism and corresponding competitions can take place. In addition, managers are expected to not neglect or handle confused guests as troublemakers but rather to respond to their concerns. In addition, this study offers pathways for ongoing research. Doubting was originally a style of decision-making; decision-making is a more stable characteristic of the decision-maker, not merely the normal pattern of action (Thunholm, 2004). Tourists refuse to portray fish that have not yet been captured by tourism operators' networks. In market segmentation studies, the use of additional extract characteristics from these specific market segments and the development of suitable promotional approaches are therefore urgently needed.

\section{Conclusion and policy implications}

The purpose of this paper is to evaluate the knowledge, health risks of tourists, and destination personality with regard to their hesitation in southern Bangladesh-a destination recently recognized for its risky status. Several factors and their effects on hesitation, as well as perception, have also been investigated. A sample of 322 Bangladeshi prospective 
tourists was used to get the study outcomes. The Smart PLS 3.0 (SEM-Structural Equation Modeling) was run to test the study hypotheses. Our results show that AVE value of every variable is above 0.50 , the value of CR and Cronbach's Alpha is above 0.70, and the value of factor loadings is above 0.60 which are the suggested or accepted range. The NFI value is 0.899 which is close to the accepted range. Therefore, the conceptual model is best fit with the study objectives and hypotheses. Furthermore, the square root of the AVE (in bold) of all variables describes the highest result within a range of $0.839-0.872$. Thus, it is well comprehensible that discriminant validity is sustained among the variables and accredited for this estimated model of the study.

The results of the study reveal a positive and significant relationship between tourist knowledge and tourist health risk with tourist hesitation. It is, therefore, concluded that any increase or decrease in tourist knowledge will influence tourist hesitation to travel to tourist places. We did not find any conventional relationship between destination personality and tourist hesitation, another result that signifies that any increase or decrease in destination personality will influence tourist hesitation to travel to tourist places. Furthermore, tourist perception mediates the connection between tourist knowledge and destination personality with sound tourist hesitation, a thing that indicates that there is a role of tourist perception to increase or decrease intention between tourist knowledge and destination personality with tourist hesitation. Besides, our study claims that tourist perception does not mediate the connection between tourist health risk and tourist hesitation; this result indicates that there is no role in tourist perception.

Tourist hesitation study has mainly underscored the magnitude of destinations and discussed a wide range of tourism marketing strategies (Kerstetter \& Pennington-Gray, 1999; Pan \& Ryan, 2007). However, the results suggest that travel agents perceive both men and women to be equally important instead of only evaluating the needs of individual tourists while promoting or selling tourism products and services. In addition, tourism managers should focus on shaping actual destination images and try to explain all relevant information to prevent tourism hesitations and decision-making regarding the destination. Initially, hesitation was one of the decisions that were not only a natural pattern of operation but also a trustworthy characteristic of decision-makers (Thunholm, 2004). Moreover, it seems that tourism managers have not paid adequate attention to hesitating tourists. More studies on the segmentation of the industry, the implementation of the reluctant characteristics of this particular sector, and the effective promotional approaches are, therefore, urgently needed (Jahanshahi \& Brem, 2018).

With reference to the results of this study, it would be possible to extend this study by further analysis of the idea of tourist hesitation and the rationale for decision-making to understand the effect of perception differences on hesitation and by using other behavioral factors such as the updated guide to the impact of gender differences on tourism decisions. In general, it is always misleading that there is no loss when tourists fail to make choices about the destination. Tourist hesitation, however, poses difficulties for tourism professionals to persuade tourists to make their transactions quickly and to increase the chance of consumers being diverted to other travel companies that adversely affect the quality of their sales. From a tourist's point of view, hesitation is, which may lead to the perfect tour being overlooked due to the perishability of satisfaction, is subjective, whereas other travel agencies offer similar trips at different prices and itineraries. However, looking at other journeys will take longer to collect information and make new decisions. Hence, tourism professionals are supposed to focus their attention on the reduction in tourists' hesitation.

The evolution of the theory of understanding tourism is a cross-relation among economics, tourism, psychology and other topics. Subjective tourism insights are more prevalent in 
theoretical and empirical studies, although the study of tourism measurement and description are comparatively less prevalent (Afshar Jahanshahi \& Brem, 2019). The paper attempts to examine perception and hesitation from the point of view of the management of the safety of travel and the spatial frameworks of tourism. Regardless of the need for fluidity, tourists were held in place by patterns and waterways, thereby imitating congestion and beyond local parking capacity. A range of temporary events and monitoring manuals tailored to a straight-time clock pose a problem for tourists. While there is a need to go with the flow, transport adaptability and speed to achieve destinations should be addressed. Pandemics emerge infrequently, yet COVID-19 impact slowed down the economy of every region. It demotivated prospective tourists to spend their holidays in their desired destinations. Nonetheless, prospective tourists will travel to attractive tourist places when they feel safe and comfortable to move on. With the huge drive of vaccination against COVID-19, tourism industry will definitely pick up momentum.

It is difficult to predict social and political transition in light of these results of this study. In any event, it is important to understand how these results are identified with evolving climate change mitigation strategies for the future of low-carbon travel industry. This is viewed in terms of the government policy and the strategy of the tourism industry. To begin with, the government's contact policy should be used to subvert discourses that maintain unsustainable practices, such as the intelligibility of traveling disputes, and to establish strong, moderate travel perception. There is an opportunity for developing new stories about tourism travel that direct people to more sustainable practices. Governments and decision-makers should rely on these factors and ensure protection for tourists and mitigate health risks. Leaving these problems behind, no country will survive any global pandemic, consequently, their economies and GDP growth would be damaged. This is the moment to support the global economy with great prosperity, and sustainable tourism can deliver this blessing without investment.

\subsection{Limitations and future studies}

Each research has to face some difficulties or limitations after it has been completed; this research is not above these limits. The underlying significant limitation that we face in the present study is that it was conducted before the emergency case caused by the latest global pandemic. Subsequently, features such as shifts in behavior, inspirations and perceptions relevant to and brought on by this new situation were not considered at any time. Conversely, the research focused on exploring factors affecting tourists' hesitation to travel. Without exception, this relevance would be motivated by this current situation. Subsequently, it would be extraordinarily useful to emulate this function in the future, as full mobility within national regions begins to be allowed and tourists are allowed worldwide. An aspect that was not addressed in this study is the consequences that a destination would have had, but did not take the inspiration for its choice.

Due to the distinctive government campaigns that are, by and large, designed to achieve indicative benefits by visiting those destinations, we believe that this aspect will change due to the increased impact felt by the tourist. It is, therefore, necessary to discover the prescriptions that help the tourism sector. Improving sustainable tourism will help to ease the obvious reluctance of tourists to visit destinations with tremendous centralization of individuals. Subsequently, it will also be intriguing to bring a study that considers the activities carried out by the tourism offer to validate its impact on the sustainable development of tourism. In future studies, tourists' attitudes can be used as a moderator among 
the relationships of knowledge, health risk, and destination personality with tourist hesitation. This study mainly focused on a developing country like Bangladesh. Therefore, future studies can be conducted in developed countries (i.e. Singapore, Malaysia, UAE, USA, Italy, and so on).

\section{Appendix}

\section{Measurement Scale}

Tourist Knowledge (Wong \& Yeh, 2009)

1. Compared to average person, I am familiar with a wide variety of vacation destinations. Compared to my friends, I am familiar with a wide variety of vacation destinations.

2. Compared to people who travel a lot, I am familiar with a wide variety of vacation destinations.

3. When I have to make a decision, I wait a long time before starting to think about it.

Tourist Health Risk (Wong \& Yeh, 2009)

1. Tourists should avoid visiting some destinations which have been attacked by natural calamities.

2. I feel nervous about traveling right now as it has extremely health risk.

3. I wouldn't feel very comfortable traveling anywhere right now due to health risk.

4. Domestic travel is just as risky as international travel regarding physical health.

Destination Personality (Lee \& Xie, 2011)

1. The visiting place is not reliable now.

2. The visiting place is not efficient to entertain now.

3. The visiting place is still Charming.

4. The visiting place is Romantic as well now.

Tourist Perception (Lee \& Xie, 2011)

1. Safety is the most important attribute a destination can offer.

2. Safety is the most serious consideration when I am choosing a destination.

3. Visits to other parks and campgrounds should be avoided right now.

4. Trips to natural area scenic attractions are safer right now.

Tourist Hesitation (Lee \& Xie, 2011)

1. I avoid making decision when I choosing a destination.

2. I put off making decision when I choosing a destination.

3. I'd rather someone else make a decision for me so that it won't be my problem.

4. I don't like to take responsibility for making decisions about choosing a destination now. 
Intention to Revisit (Artuğer, 2015)

N.B.: A small study on the intention to revisit was conducted in the light of the pandemic (COVID-19)

1. If I come to travel again my first choice will be Cox's Bazar.

2. I plan to come to Cox's Bazar again in the future.

3. The probability that I come to Cox's Bazar again for holidays is high.

Acknowledgements Mohammad Rashed Hasan Polas coordinated the project and drafted this paper; Ratul Kumar Saha provided conceptual input and comments contributed to writing/revising main parts of the article; Dr. Mosab I. Tabash contributed to data collection, data analysis and formatting the paper.

Authors' contributions All the authors contributed equally.

Funding There is no funding for this study. Authors have completed it by their own expenses.

Availability of data and material Not Applicable.

Code availability Not Applicable.

Declarations

Conflicts of interest There is no conflict of interests among authors.

\section{References}

Aaker, J. L. (1997). Dimensions of brand personality. Journal of Marketing Research, 34(3), 347-356.

Afshar Jahanshahi, A., \& Brem, A. (2019). Entrepreneurs in post-sanctions Iran: Innovation or imitation under conditions of perceived environmental uncertainty? Asia Pacific Journal of Management, 37(2), 531-551. https://doi.org/10.1007/s10490-018-9618-4

Afshar Jahanshahi, A., Brem, A., \& Hoerauf, D. (2020a). Employee creativity in war zones: Empirical evidence from small firms in Afghanistan. Creativity and Innovation Management, 29(3), 465-480.

Afshar Jahanshahi, A., Maghsoudi, T., \& Shafighi, N. (2020b). Employees' environmentally responsible behaviour: The critical role of environmental justice perception. Sustainability: Science, Practice and Policy, 17(1), 1-14. https://doi.org/10.1080/15487733.2020.1820701

Ahmed, O., Ahmed, M. Z., Alim, S. M. A., Khan, M. A. U., \& Jobe, M. C. (2020). COVID-19 outbreak in Bangladesh and associated psychological problems: An online survey. Death Studies, 11, 1-10.

Amin, M. R. (2017). Domestic tourists' mind-set towards responsible tourism management: A case study on Cox's Bazar Bangladesh. International Journal of Tourism Cities, 3(2), 121-142.

Anable, J., \& Gatersleben, B. (2005). All work and no play? The role of instrumental and affective factors in work and leisure journeys by different travel modes. Transportation Research Part A: Policy and Practice, 39(2-3), 163-181.

Anderson, N. H. (1981). Foundations of information integration theory. Academic Press.

Armstrong, J. S., \& Overton, T. S. (1977). Estimating nonresponse bias in mail surveys. Journal of Marketing Research, 14(3), 396-402.

Artuğer, S. (2015). The effect of risk perceptions on tourists' revisit intentions. European Journal of Business and Management, 7(2), 36-43.

Badulescu, A., Badulescu, D., Simut, R., \& Dzitac, S. (2020). Tourism-economic growth nexus. The case of Romania. Technological and Economic Development of Economy, 26(4), 867-884.

Baloglu, S., Henthorne, T. L., \& Sahin, S. (2014). Destination image and brand personality of Jamaica: A model of tourist behavior. Journal of Travel \& Tourism Marketing, 31(8), 1057-1070.

Banik, R., Rahman, M., Hossain, M. M., Sikder, M. T., \& Gozal, D. (2020) COVID-19 pandemic and Rohingya refugees in Bangladesh: What are the major concerns?. Global Public Health, 1-4. 
Bansal, H., \& Eiselt, H. A. (2004). Exploratory research of tourist motivations and planning. Tourism Management, 25(3), 387-396.

Barbhuiya, M. R., \& Chatterjee, D. (2020). Vulnerability and resilience of the tourism sector in India: Effects of natural disasters and internal conflict. Tourism Management Perspectives, 33, 100616.

Begum M., Farid, M. S., Alam, M. J., \& Barua, S. (2020). COVID-19 and Bangladesh: socio-economic analysis towards the future correspondence. Asian Journal of Agricultural Extension, Economics \& Sociology 143-155.

Beneke, J., Flynn, R., Greig, T., \& Mukaiwa, M. (2013). The influence of perceived product quality, relative price and risk on customer value and willingness to buy: A study of private label merchandise. Journal of Product \& Brand Management, 22(3), 218-228.

Berger, I. E., Ratchford, B. T., \& Haines, G. H., Jr. (1994). Subjective product knowledge as a moderator of the relationship between attitudes and purchase intentions for a durable product. Journal of Economic Psychology, 15(2), 301-314.

Berglund, T., Gericke, N., Boeve-de Pauw, J., Olsson, D., \& Chang, T. C. (2019). A cross-cultural comparative study of sustainability consciousness between students in Taiwan and Sweden. Environment, Development and Sustainability, 22, 1-27.

Bhattacharjee, A., Polas, M. R. H., \& Rahman, M. L. (2018). Challenges and Prospects of Tourism in Cox's Bazar: An Empirical Study. Journal of Business and Technology (dhaka), XIII(1), 63-82.

Biel, A. L. (1993). Converting image into equity. Brand Equity and Advertising: Advertising's Role in Building Strong Brands, 26(10), 67-81.

Bonham, C., Edmonds, C., \& Mak, J. (2006). The impact of 9/11 and other terrible global events on tourism in the United States and Hawaii. Journal of Travel Research, 45(1), 99-110.

Boshoff, C. (2002). Service advertising: An exploratory study of risk perceptions. Journal of Service Research, 4(4), 290-298.

Cahyanto, I., Wiblishauser, M., Pennington-Gray, L., \& Schroeder, A. (2016). The dynamics of travel avoidance: The case of Ebola in the US. Tourism Management Perspectives, 20, 195-203.

Carballo, R. R., Leon, C. J., \& Carballo, M. M. (2017). The perception of risk by international travellers. Worldwide Hospitality and Tourism Themes, 9(5), 534-542.

Carvache-Franco, M., Víquez-Paniagua, A. G., Carvache-Franco, O., Perez-Orozco, A., \& CarvacheFranco, W. (2019). Motivations, intentions to return and to recommend protected areas: A study In Costa Rica. GeoJournal of Tourism and Geosites, 27(4), 1173-1183.

Chen, C. F., \& Chou, S. H. (2019). Antecedents and consequences of perceived coolness for Generation $\mathrm{Y}$ in the context of creative tourism-A case study of the Pier 2 Art Center in Taiwan. Tourism Management, 72, 121-129.

Chen, C. F., \& Phou, S. (2013). A closer look at destination: Image, personality, relationship and loyalty. Tourism Management, 36, 269-278.

Chen, L., Li, Y. Q., \& Liu, C. H. (2019). How airline service quality determines the quantity of repurchase intention-Mediate and moderate effects of brand quality and perceived value. Journal of Air Transport Management, 75, 185-197.

Chen, X., \& Chen, H. (2019). Comparing environmental impacts of Chinese Torreya plantations and regular forests using remote sensing. Environment, Development and Sustainability, 1-18.

Cherkani, N., \& Brito, P. Q. (2018). Tourists' Precautions in an Unsafe Destination: The Case of Agadir, Morocco. In Innovative Approaches to Tourism and Leisure (pp. 573-581). Springer, Cambridge.

Chien, P. M., Sharifpour, M., Ritchie, B. W., \& Watson, B. (2017). Travelers' health risk perceptions and protective behavior: A psychological approach. Journal of Travel Research, 56(6), 744-759.

Cho, C. H., Kang, J., \& Cheon, H. J. (2006). Online Shopping Hesitation. Cyberpsychology \& Behavior, 9(3), 261-274.

Cohen, N. J., \& Squire, L. R. (1980). Preserved learning and retention of pattern-analyzing skill in amnesia: Dissociation of knowing how and knowing that. Science, 210(4466), 207-210.

Comrey, A. L., \& Lee, H. B. (1992). Interpretation and application of factor analytic results. In A. L. Comrey \& H. B. Lee (Eds.), A First Course in Factor Analysis (2nd ed., p. 2). Lawrence Erlbaum Associates.

Cui, F., Liu, Y., Chang, Y., Duan, J., \& Li, J. (2016). An overview of tourism risk perception. Natural Hazards, 82(1), 643-658.

Deb, S. K., \& Nafi, S. M. (2020). Impact of COVID-19 Pandemic on Tourism: Perceptions from Bangladesh. Available at SSRN 3632798.

Delbridge, A., \& Bernard, J. R. L. (1998). The concise macquarie english dictionary. Macquarie University.

Dhar, R. (1997). Consumer preference for a no-choice option. Journal of Consumer Research, 24(2), 215-231. 
Dhaka Tribune (2021a). Cox's Bazar poised to see 1 million tourist rush next weekend as Covid-19 cases drop. Available at: https://www.dhakatribune.com/bangladesh/nation/2021/02/14/cox-sbazar-poised-to-see-1-million-tourist-rush-next-weekend-as-covid-19-cases-drop.

Dhaka Tribune (2021b). Cox's Bazar closed for tourists until April 14. Available at: https://www.dhaka tribune.com/bangladesh/nation/2021/04/02/cox-s-bazar-tourist-hubs-declared-closed-till-april-14.

Dhebar, A. (1996). Speeding high-tech producer, meet the balking consumer. Sloan Management Review, 37(2), 37-50.

Dolnicar, S., (2007). Crises" that scare tourists: Investigating tourists' travel-related concerns. Crisis management in tourism 98-109.

Drimili, E., Gareiou, Z, \& Zervas, E. (2020). Public perceptions of the concept of green growth: Application in Athens, Greece, during a period of economic crisis. Environment, Development and Sustainability, 22(7), 6053-6076.

Dwyer, L., Forsyth, P., \& Dwyer, W. (2020). Tourism economics and policy. Channel View Publications.

Ekinci, Y., \& Hosany, S. (2006). Destination personality: An application of brand personality to tourism destinations. Journal of Travel Research, 45(2), 127-139.

Fermani, A., Sergi, M. R., Carrieri, A., Crespi, I., Picconi, L., \& Saggino, A. (2020). Sustainable tourism and facilities preferences: The sustainable tourist stay scale (STSS) validation. Sustainability, 12(22), 9767.

Fischer, G. W., Morgan, M. G., Fischhoff, B., Nair, I., \& Lave, L. B. (1991). What risks are people concerned about. Risk Analysis, 11(2), 303-314.

Floyd, M. F., \& Pennington-Gray, L. (2004). Profiling risk perceptions of tourists. Annals of Tourism Research, 31(4), 1051-1054.

Fornell, C., \& Larcker, D. F. (1981). Structural equation models with unobservable variables and measurement error: Algebra and statistics.

Fuchs, G., \& Reichel, A. (2006). Tourist destination risk perception: The case of Israel. Journal of Hospitality \& Leisure Marketing, 14(2), 83-108.

Fuchs, G., Uriely, N., Reichel, A., \& Maoz, D. (2013). Vacationing in a terror-stricken destination: Tourists' risk perceptions and rationalizations. Journal of Travel Research, 52(2), 182-191.

Gabrieli, J. D. (1998). Cognitive neuroscience of human memory. Annual Review of Psychology, 49(1), $87-115$.

Garg, A. (2015). Travel risks vs tourist decision making: A tourist perspective. International Journal of Hospitality \& Tourism Systems, 8(1), 1-9.

Gartner, W. C. (1986). Temporal influences on image change. Annals of Tourism Research, 13(4), 635-644.

Gharleghi, B., \& Jahanshahi, A. A. (2020). The way to sustainable development through income equality: The impact of trade liberalisation and financial development. Sustainable Development, 28(4), 990-1001.

Gill, J., \& Ibrahim, E. E. B. (2005). A positioning strategy for a tourist destination, based on analysis of customer's perceptions and satisfactions. Marketing Intelligence and Planning, 23(2), 172-188.

Glaesser, D. (2003). Crises' spheres of activity. Crisis management in the tourism industry. Burlington, MA: Elsevier Butterworth-Heinemann.

Gursoy, D., \& McCleary, K. W. (2004). An integrative model of tourists' information search behavior. Annals of Tourism Research, 31(2), 353-373.

Hafsa, S. (2020). Impacts of COVID-19 Pandemic on Tourism \& Hospitality Industry in Bangladesh. Available at SSRN 3659196.

Hair, J. F., Jr., Sarstedt, M., Hopkins, L., \& Kuppelwieser, V. G. (2014). Partial least squares structural equation modeling (PLS-SEM). European Business Review, 26(2), 106-121.

Hanefeld, J., Lunt, N., Smith, R., \& Horsfall, D. (2015). Why do medical tourists travel to where they do? The role of networks in determining medical travel. Social Science \& Medicine, 124, 356-363.

Hasan, M. K., Ismail, A. R., \& Islam, M. F. (2017). Tourist risk perceptions and revisit intention: A critical review of literature. Cogent Business \& Management, 4(1), 1412874.

He, X., Hu, D., Swanson, S. R., Su, L., \& Chen, X. (2018). Destination perceptions, relationship quality, and tourist environmentally responsible behavior. Tourism Management Perspectives, 28, 93-104.

Hew, J. J., Leong, L. Y., Tan, G. W. H., Lee, V. H., \& Ooi, K. B. (2018). Mobile social tourism shopping: A dual-stage analysis of a multi-mediation model. Tourism Management, 66, 121-139.

Hosany, S., Ekinci, Y., \& Uysal, M. (2006). Destination image and destination personality: An application of branding theories to tourism places. Journal of Business Research, 59(5), 638-642.

Hossain, M. M. (2020). Influential factors of tourists' satisfaction in Bangladesh: Evidence from selected tourism destinations at Cumilla region. Canadian Journal of Business and Information Studies, 2(4), 75-86. 
Hossain, M. M., Mazumder, H., Tasnim, S., Nuzhath, T., \& Sultana, A. (2020). Geriatric health in Bangladesh during COVID-19: challenges and recommendations. Journal of Gerontological Social Work, 63, 1-4.

Huat, J., Fusillier, J. L., Dossou-Yovo, E., Lidon, B., Kouyaté, A. M., Touré, A., \& Hamadoun, A. (2019). Benefits and limits of inland valley development to enhance agricultural growth: a farmers' perception approach in southern Mali. Environment, Development and Sustainability, 22, 1-19.

Hultman, M., Skarmeas, D., Oghazi, P., \& Beheshti, H. M. (2015). Achieving tourist loyalty through destination personality, satisfaction, and identification. Journal of Business Research, 68(11), 2227-2231.

Islam, M. S., Roy, S., Afrin, R., \& Mia, M. Y. (2020). Influence of climate-induced disasters and climatic variability on cropping pattern and crop production in Bangladesh. Environment, Development and Sustainability, 22(7), 6709-6726.

Jabbari, M., Motlagh, M. S., Ashrafi, K., \& Abdoli, G. (2019). Differentiating countries based on the sustainable development proximities using the SDG indicators. Environment, Development and Sustainability, 22, 1-19.

Jahanshahi, A. A., \& Brem, A. (2018). Antecedents of Corporate Environmental Commitments: The Role of Customers. International Journal of Environmental Research and Public Health, 15(6), 1191.

Jiang, Y., \& Ritchie, B. W. (2017). Disaster collaboration in tourism: Motives, impediments and success factors. Journal of Hospitality and Tourism Management, 31, 70-82.

Jonas, A., \& Mansfeld, Y. (2017). Exploring the interplay between the use of risk-related information, risk perception formation, and the stages of travel product consumption. Current Issues in Tourism, 20(14), 1470-1488.

Jonas, A., Mansfeld, Y., Paz, S., \& Potasman, I. (2011). Determinants of health risk perception among lowrisk-taking tourists traveling to developing countries. Journal of Travel Research, 50(1), 87-99.

Kärle, E., Şimşek, U., Panasiuk, O., \& Fensel, D. (2018). Building an ecosystem for the tyrolean tourism knowledge graph. In: International Conference on Web Engineering (pp. 260-267). Springer, Cambridge.

Kerstetter, D., \& Pennington-Gray, L. (1999). Decision-making roles adopted by university-educated women who travel for pleasure. Journal of Hospitality \& Leisure Marketing, 6(3), 23-39.

Khan, M. J., Chelliah, S., \& Ahmed, S. (2017a). Factors influencing destination image and visit intention among young women travellers: Role of travel motivation, perceived risks, and travel constraints. Asia Pacific Journal of Tourism Research, 22(11), 1139-1155.

Khan, M. J., Chelliah, S., Haron, M. S., \& Ahmed, S. (2017b). Push factors, risks, and types of visit intentions of international medical travelers-A conceptual model. International Journal of Healthcare Management, 10(2), 115-121.

Kogo, B. K., Kumar, L., \& Koech, R. (2020). Climate change and variability in Kenya: a review of impacts on agriculture and food security. Environment, Development and Sustainability, 23, 1-21.

Korstanje, M. E. (2011). The fear of traveling: A new perspective for tourism and hospitality. Anatolia, $22(2), 222-233$.

Lalicic, L., \& Önder, I. (2018). Residents' involvement in urban tourism planning: Opportunities from a smart city perspective. Sustainability, 10(6), 1852.

Lee, J., \& L. K. Xie. (2011). Cognitive Destination Image, Destination Personality and Behavioral Intentions: An Integrated Perspective of Destination Branding. Paper presented at the 16th Graduate Students Research Conference. University of Massachusetts, Amherst, MA.

Lepp, A., \& Gibson, H. (2003). Tourist roles, perceived risk and international tourism. Annals of Tourism Research, 30(3), 606-624.

Li, J., Feng, Y., Li, G., \& Sun, X. (2020). Tourism companies' risk exposures on text disclosure. Annals of Tourism Research, 84, 102986.

LightCastle Analytics Wing. (2020). COVID-19 \& Tourism: A Tragic End to the Thriving Industry? Available at: https://databd.co/stories/covid-19-tourism-a-tragic-end-to-thethrivingindustry11643?fbclid= IwAR38rssRnAsJj34OSmZmtpZQDXk72FpAEV3ZL_bm7QdAceKRgdGNm ML9hMQ. (viewed 10 June 2020).

Lin, H., Zhang, M., Gursoy, D., \& Fu, X. (2019). Impact of tourist-to-tourist interaction on tourism experience: The mediating role of cohesion and intimacy. Annals of Tourism Research, 76, 153-167.

Liu, J., Liu, N., Zhang, Y., Qu, Z., \& Yu, J. (2019). Evaluation of the non-use value of beach tourism resources: A case study of Qingdao coastal scenic area, China. Ocean \& Coastal Management, 168, $63-71$.

Liu, Y. (2009). Risk society theory and application value. Zhejiang Soc Sci, 3, 64-70.

Lu, A. C. C., Gursoy, D., \& Lu, C. Y. R. (2016). Antecedents and outcomes of consumers' confusion in the online tourism domain. Annals of Tourism Research, 57, 76-93. 
Majumder, J., \& Iqbal, M. M. (2018). Measuring impact of word-of-mouth on travel: A study based on Bangladeshi tourists' experience at cox's bazar. Journal of Business, 39(1).

Malhotra, D. (2004). Trust and reciprocity decisions: The differing perspectives of trustors and trusted parties. Organizational Behavior and Human Decision Processes, 94(2), 61-73.

Mason, M. C., Gos, L., \& Moretti, A. (2016). Motivations, perceived risk and behavioural intentions in hard adventure tourism A natural park case study. Sinergie Italian Journal of Management, 34, 181-199.

Mishra, P. K., Rout, H. B., \& Mohapatra, S. S. (2011). Causality between tourism and economic growth: Empirical evidence from India. European Journal of Social Sciences, 18(4), 518-527.

Mohamad, M., Abdullah, A. R., \& Mokhlis, S. (2012). Tourists' evaluations of destination image and future behavioral intention: The case of Malaysia. Journal of Management and Sustainability, 2, 181.

Mohebali, S., Maghsoudy, S., Ardejani, F. D., \& Shafaei, F. (2019). Developing a coupled environmental impact assessment (C-EIA) method with sustainable development approach for environmental analysis in coal industries. Environment, Development and Sustainability, 22, 1-32.

Monsarrat, S., Boshoff, A. F., \& Kerley, G. I. (2019). Accessibility maps as a tool to predict sampling bias in historical biodiversity occurrence records. Ecography, 42(1), 125-136.

Morgan, N. (2002). Contextualizing Destination Branding. In N. Morgan, A. Pritchard, \& R. Pride (Eds.), A destination branding: Creating the unique destination proposition (pp. 11-41). Oxford: Butterworth-Heinemann.

Murphy, P., Pritchard, M. P., \& Smith, B. (2000). The destination product and its impact on traveller perceptions. Tourism Management, 21(1), 43-52.

Nadeau, J., Heslop, L., O'Reilly, N., \& Luk, P. (2008). Destination in a country image context. Annals of Tourism Research, 35(1), 84-106.

Ngo, T., Hales, R., \& Lohmann, G. (2019). Collaborative marketing for the sustainable development of community-based tourism enterprises: A reconciliation of diverse perspectives. Current Issues in Tourism, 22(18), 2266-2283.

Nhamo, G., Dube, K., \& Chikodzi, D. (2020). The context: COVID-19, global development agendas and tourism. In Counting the cost of COVID-19 on the global tourism industry (pp. 3-24). Springer.

Page, S. J. (2009). Current issue in tourism: The evolution of travel medicine research: A new research agenda for tourism? Tourism Management, 30(2), 149-157.

Pal, S., Mahato, S., Giri, B., Pandey, D. N., \& Joshi, P. K. (2021). Quantifying monthly water balance to estimate water deficit in Mayurakshi River basin of Eastern India. Environment, Development and Sustainability, 1-29.

Pan, S., \& Ryan, C. (2007). Mountain areas and visitor usage-motivations and determinants of satisfaction: The case of Pirongia Forest Park, New Zealand. Journal of Sustainable Tourism, 15(3), 288-308.

Park, C. W., Mothersbaugh, D. L., \& Feick, L. (1994). Consumer knowledge assessment. Journal of Consumer Research, 21(1), 71-82.

Park, E., Choi, B. K., \& Lee, T. J. (2019). The role and dimensions of authenticity in heritage tourism. Tourism Management, 74, 99-109.

PATA Bangladesh Chapter. (2020). PATA Bangladesh Chapter: COVID-19 impact on the Tourism Industry in Bangladesh. Available at:https://www.pata.org/pata-bangladeshchapter-covid-19-impact-on-thetourism-industry-in bangladesh/\#sthash.ZgATKzlW.dpuf. (viewed 11 June 2020).

Peattie, S., Clarke, P., \& Peattie, K. (2005). Risk and responsibility in tourism: Promoting sun-safety. Tourism Management, 26(3), 399-408.

Peng, N., \& Chen, A. (2019). Luxury hotels going green-the antecedents and consequences of consumer hesitation. Journal of Sustainable Tourism, 27(9), 1374-1392.

Pforr, C., 2009. Crisis management in tourism: A review of the emergent literature. In Crisis management in the tourism industry: Beating the odds (pp. 37-52). Ashgate.

Polas, M. R. H., Hossain, M. I., Tabash, M. I., Karim, A. M., Dad, A., \& San, O. T. (2020). Does green entrepreneurial intention persuade an individual to contribute to the sustainable green economy? Talent Development \& Excellence, 12(2), 1142.

Polas, M. R. H., Jahanshahi, A. A., \& Rahman, M. L. (2018). Islamic branding as a tool for customer retention: Antecedents and consequences of islamic brand loyalty. International Journal of Islamic Marketing and Branding, 3(1), 1-14.

Polas, M. R. H., \& Raju, V. (2021). Technology and entrepreneurial marketing decisions during COVID-19. Global Journal of Flexible Systems Management, 1-18, 262. https://doi.org/10.1007/ s40171-021-00262-0

Polas, M. R. H., Reza, M. M. U., \& Rowza, S. (2017). Role of advertising and service quality on tourism development in Bangladesh. IOSR Journal of Business and Management, 19(9), 77-86. 
Polas, R. H., Imtiaz, M., Mahbub, A., \& Khan, A. M. (2019). Antecedent and consequences of risk perception on tourist decision making towards the sustainable medical tourism development in Bangladesh. Journal of Tourism Management Research, 6(1), 93-108.

Pulido-Fernández, J. I., Cárdenas-García, P. J., \& Espinosa-Pulido, J. A. (2019). Does environmental sustainability contribute to tourism growth? An analysis at the country level. Journal of Cleaner Production, 213, 309-319.

Rezaei, S., \& Maihami, R. (2019). Optimizing the sustainable decisions in a multi-echelon closed-loop supply chain of the manufacturing/remanufacturing products with a competitive environment. Environment, Development and Sustainability, 22, 1-27.

Rogers, R. W. (1975). A protection motivation theory of fear appeals and attitude change1. The Journal of Psychology, 91(1), 93-114.

Russell-Bennett, R., Hartel, C., \& Mccoll-Kennedy, J. (2005). Experience as a moderator of involvement and satisfaction on brand loyalty in a business-to-business setting. Industrial Marketing Management, 34(1), 97-107.

Sadar, S., \& Rekha, R. S. (2016). Students' attitude towards beach tourism in Bangladesh: A study on Saint Martin and Cox's Bazar Sea Beaches. Bangladesh Journal of Tourism Volume, 1(1).

Shaktawat, A., \& Vadhera, S. (2020). Risk management of hydropower projects for sustainable development: a review. Environment, Development and Sustainability, 1-32.

Sönmez, S. F., \& Graefe, A. R. (1998). Determining future travel behavior from past travel experience and perceptions of risk and safety. Journal of Travel Research, 37(2), 171-177.

Spector, S. (2020). Delineating acceptable risk in the space tourism industry. Tourism Recreation Research, 45(4), 500-510.

Su, L., \& Swanson, S. R. (2019). Perceived corporate social responsibility's impact on the well-being and supportive green behaviors of hotel employees: The mediating role of the employee-corporate relationship. Tourism Management, 72, 437-450.

Suhartanto, D., Brien, A., Primiana, I., Wibisono, N., \& Triyuni, N. N. (2020). Tourist loyalty in creative tourism: The role of experience quality, value, satisfaction, and motivation. Current Issues in Tourism, 23(7), 867-879.

Sung, Y., \& Kim, J. (2010). Effects of brand personality on brand trust and brand affect. Psychology \& Marketing, 27(7), 639-661.

Swangjang, K., \& Kornpiphat, P. (2021). Does ecotourism in a Mangrove area at Klong Kone, Thailand, conform to sustainable tourism? A case study using SWOT and DPSIR. Environment, Development and Sustainability, 1-26.

Tang, C. F., \& Tan, E. C. (2015). Does tourism effectively stimulate Malaysia's economic growth? Tourism Management, 46, 158-163.

Tepavčević, J., Miljanić, U., Bradić, M., \& Janićević, S. (2019). Impact of London residents' sociodemographic characteristics on the motives for visiting national parks. Journal of the Geographical Institute Jovan Cvijic SASA, 69(2), 135-146.

Thai, N. T., \& Yuksel, U. (2017). Too many destinations to visit: Tourists' dilemma? Annals of Tourism Research, 62, 38-53.

The Daily Star. (2020). Can tourism in Cox's Bazar survive the Covid-19 effect? Available at: https:// www.thedailystar.net/opinion/news/can-tourism-coxs-bazar-survive-the-covid-19-effect-1930397.

Thompson, M. M., \& Zanna, M. P. (1995). The conflicted individual: Personality-based and domain specific antecedents of ambivalent social attitudes. Journal of Personality, 63(2), 259-288.

Thunholm, P. (2004). Decision-making style: Habit, style or both? Personality and Individual Differences, 36(4), 931-944.

Tjiptono, F., \& Yang, L. (2018). To go or not to go: a typology of Asian tourist destination avoidance. In Asian Cultures and Contemporary Tourism (pp. 183-200). Springer, Singapore.

Tsaur, S. H., Yen, C. H., \& Chen, C. L. (2010). Independent tourist knowledge and skills. Annals of Tourism Research, 37(4), 1035-1054.

Um, S., \& Crompton, J. L. (1990). Attitude determinants in tourism destination choice. Annals of Tourism Research, 17(3), 432-448.

Usakli, A., \& Baloglu, S. (2011). Brand personality of tourist destinations: An application of self-congruity theory. Tourism Management, 32(1), 114-127.

Uslu, A., \& Akay, B. (2019). Assessing the effect of international relations on tourism demand in the context of Turkey-Russia aircraft crisis. Journal of Tourism and Services, 10(18), 63-78.

Walker, L. \& Page, S., (2003). Risks, rights and responsibilities in tourist well-being: who should manage visitor well-being at the destination. Managing tourist health and safety in the new millennium, 215-235. 
Wijesinghe, S. N., Mura, P., \& Bouchon, F. (2019). Tourism knowledge and neocolonialism-a systematic critical review of the literature. Current Issues in Tourism, 22(11), 1263-1279.

Williams, A. M., \& Baláž, V. (2015). Tourism risk and uncertainty: Theoretical reflections. Journal of Travel Research, 54(3), 271-287.

Wong, J. Y., \& Yeh, C. (2009). Tourist hesitation in destination decision making. Annals of Tourism Research, 36(1), 6-23.

Xiao, H., \& Smith, S. L. (2007). The use of tourism knowledge: Research propositions. Annals of Tourism Research, 34(2), 310-331.

Yang, E. C. L., Sharif, S. P., \& Khoo-Lattimore, C. (2015). Tourists' risk perception of risky destinations: The case of Sabah's eastern coast. Tourism and Hospitality Research, 15(3), 206-221.

Yasin, B., Baghirov, F., \& Zhang, Y. (2017). The role of travel experience and gender on travel information source selection. Journal of Hospitality and Tourism Technology, 8(2), 296-310.

Zeugner-Roth, K. P., \& Žabkar, V. (2015). Bridging the gap between country and destination image: Assessing common facets and their predictive validity. Journal of Business Research, 68(9), 1844-1853.

Zheng, H., \& Lu, H. (2011). Effect of microwave pretreatment on the kinetics of ascorbic acid degradation and peroxidase inactivation in different parts of green asparagus (Asparagus officinalis L.) during water blanching. Food Chemistry, 128(4), 1087-1093.

Zhu, Z., Fu, W., \& Liu, Q. (2021). Correlation between urbanization and ecosystem services in Xiamen, China. Environment, Development and Sustainability, 23(1), 101-121.

Zou, Y., \& Meng, F. (2020). Chinese tourists' sense of safety: Perceptions of expected and experienced destination safety. Current Issues in Tourism, 23(15), 1886-1899.

Publisher's Note Springer Nature remains neutral with regard to jurisdictional claims in published maps and institutional affiliations.

\section{Authors and Affiliations}

\section{Mohammad Rashed Hasan Polas ${ }^{1}$ D $\cdot$ Ratul Kumar Saha $^{2} \cdot$ Mosab I. Tabash $^{3}$}

Ratul Kumar Saha

ratul@juniv.edu

Mosab I. Tabash

mosab.tabash@aau.ac.ae

1 Institute of Scientific Research and Graduate School, Universidad de Lima, Javier Prado Este 4600, Santiago de Surco, 15023 Lima, Peru

2 Institute of Business Administration, Jahangirnagar University, Dhaka, Bangladesh

3 College of Business, Al Ain University, Al Ain, UAE 